Володимир Іванович Коцюруба (доктор технічни наук, доцент) ${ }^{1}$ Анатолій Степанович Довгополий (доктор технічних наук, професор) ${ }^{2}$ Олег Михайлович Гусляков (кандидт технічних наук) ${ }^{2}$ Микола Павлович Лойко ${ }^{3}$

${ }^{1}$ Національний університет оборони Украӥни імені Івана Черняховського, Київ, Украӥна ${ }^{2}$ Центрального науково-дослідного інституту озброєння та військової техніки Збройних Сил, Київ, Украӥна

${ }^{3}$ Товариство з обмеженою відповідальністю “Юг-нафтогазгеологія”, Київ, Украӥна

\title{
ДОСЛІДЖЕННЯ МОЖЛИВОСТІ ВИКОРИСТАННЯ НЕВИБУХОВОГО ІМПУЛЬСНОГО СЕЙСМІЧНОГО ДЖЕРЕЛА ДЛЯ ЗНИЩЕННЯ ВИБУХОВИХ ПРИСТРОЇВ
}

Досліджується проблема гуманітарного розмінування та можливість використання приниипу діï, щуо покладено в основу невибухового імпульсного сейсмічного джерела для знищення (знешкодження) вибухових пристроїв з різними датчиками иялі, які встановлені на суші або у воді. Як невибухове імпульсне сейсмічне джерело застосовано дослідний зразок електродинамічного імпульсного джерела сейсмічних сигналів ІДД-27, щз надано товариством з обмеженою відповідальністю "Югнафтогазгеологія". На основі аналізу результатів проведеного комплексного натурного експерименту перевірені гіпотези щьоо можливості використання пристрою даного типу для знищення (знешкодження) вибухових пристроїв иляхом впливу збуджених поверхневих і епіцентральних сейсмічних та електромагнітних хвиль на контактні або неконтактні датчики цілі вибухових пристроїв. Як контактні використовувались макети обривних (натяжних), натискних, итирьових, сейсмічних датчиків цілі протитанкових, протитраспортних, об'єктних, протипіхотних мін, мін-сюрпризів та саморобних вибухових пристроїв, а також итирьових датчиків цілі протидесантних мін.

Крім того вимірювання параметрів розповсюдження сейсмічних хвиль здійснювалось за допомогою ичифрової сейсмічної станиії TEXAN-125A з сейсмодатчиками GS-11D та сейсмографа Guralp CMD 40TD. 3 метою встановлення можливості знищення (знешкодження) вибухових пристроїв із неконтактними магнітними датчиками иілі проводилось дистанційне вимірювання параметрів розповсюдження електромагнітних хвиль від дї електродинамічного імпульсного джерела сейсмічних сигналів ІДД-27 за допомогою магнітотелуричної станції LEMI-423. Аналіз одержаних результатів показав неоднозначність в питаннях можливості використання розглянутого принципу дї невибухового імпульсного сейсмічного джерела для знищення (знешкодження) вибухових пристроїв з різними датчиками цілі на суші та у воді.

Ключові слова: гуманітарне розмінування; знищення (знешкодження); датчик иілі; вибуховий пристрій; вибухонебезпечний предмет; невибухове імпульсне сейсмічне джерело; сейсмічні хвилі; електромагнітне випромінювання.

\section{Ветуп}

Постановка проблеми. Внаслідок бойових дій на сході нашої країни значна територія Донецької та Луганської областей забруднена вибухонебезпечними предметами (ВНП). За попередніми оцінками площа звільненої території та території, яка тимчасово непідконтрольна нашій державі, що вважаються мінно-небезпечними, складає близько 23000 км2, на якій проживає більш ніж 5 млн. громадян [1]. За наявною інформацією ця територія замінована та забруднена ВНП, що буде потребуватиме гуманітарного розмінування після встановлення на цій території державного контролю. До того ж, постійні обстріли з боку незаконних збройних формувань, які проводяться у порушення Мінських домовленостей, призводять до нових руйнувань та забрудненню території ВНП.

Аналіз втрат особового складу, озброєння i військової техніки у ході антитерористичної операції та операції Об'єднаних сил на території Донецької та Луганської областей показав, що від підриву на мінах отримані втрати в особовому складі та бойової та спеціальної техніки є значним. Найбільш критичним виявися 2015 рік. У 2015 році за даними Стокгольмського інституту Миру за кількістю втрат Україна займає 5 місце випереджаючі Афганістан, Камбоджу, Малі та Пакистан [1].

За даними Управління екологічної безпеки та протимінної діяльності 3 початком бойових дій на території Донецької та Луганської областей в наслідок підриву на мінах постраждало близько 1900 цивільних осіб (близько 500 загинуло, з них більш 20 - діти) [2].

Досвід виконання завдань 3 розмінування у воєнних конфліктах сучасності та миротворчих операціях [3-7] показав, що темпи розвитку мінної зброї значно перевищують темпи розвитку (C) В.І.Коцюруба, В.С.Довгополий, О.М.Гусляков, М.П.Лойко Modern Information Technologies in the Sphere of Security and Defence № 3(36)/2019 ISSSN2311-7249(Print)/ISSN2410-7336(Online) 
протимінних засобів. Цей факт, враховуючи зростаючу інтенсивність застосування мін та саморобних вибухових пристроїв, у провідних країнах світу давно вже сприймається як загальносвітова проблема, вирішення якої потребує комплексного підходу [8]. При цьому, особлива увага в операціях по розмінуванню приділяється якості очищення місцевості від ВНП, що визначається міжнародними стандартами 3 розмінування [9].

Взагалі, на даний час не існує ні одного технічного засобу, який би забезпечував виконання вимог [9], що і обумовлює подальше поширене застосування ручного способу розмінування, який є вкрай небезпечним. Отже, враховуючі все вищезазначене, в практиці розмінування існує потреба значного підвищення якості розмінування за рахунок застосування ефективних засобів пошуку (виявлення), знищення (знешкодження) вибухових пристроїв (ВП). Одним iз перспективних напрямків розвитку протимінних засобів є впровадження новітніх принципів дії у процеси розмінування, до яких відноситься використання енергії сейсмічних хвиль, що виникають внаслідок штучного впливу невибухового імпульсного сейсмічного джерела (НІСД) на укриваючі середовища.

Аналіз останніх досліджень і публікацій [1016] показав, що в них піднято та розглянуто часткові наукові задачі. Так відомі праці $[10,11]$ присвячені висвітленню результатів наукових досліджень, спрямованих на моделювання процесів та обгрунтування вимог до засобів пошуку та виявлення ВНП різними методами. При цьому, в [10] розглядається можливість та наведені залежності щодо виявлення великих об'єктів та

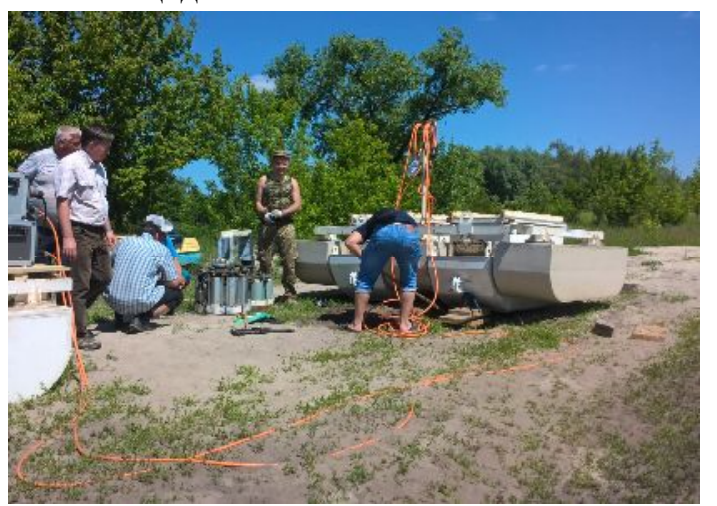

a. перехідних шарів у грунтах сейсмоакустичним методом. Вказаний метод поки що не знайшов поширеного використання у практиці розмінування. У [12-16] наведені результати експериментальних та теоретичних досліджень способів знищення (знешкодження) ВП, до основних з яких належать вибуховий, механічний, лазерний тощо.

Проведений аналіз відомих доступних досліджень і публікацій дозволив дійти висновку, що задача проведення комплексних експериментальних досліджень можливості використання енергії НІСД, як засобу знищення (знешкодження) ВП, не ставилась, а отже і не вирішувалась.

Мета статті полягає у висвітлені основних результатів проведеного натурного експерименту щодо дослідження можливості використання НІСД для знищення (знешкодження) ВП під час гуманітарного розмінування.

\section{Виклад основного матеріалу дослідження}

В якості робочої гіпотези було використано твердження щодо можливості використання штучного невибухового імпульсного методу збудження сейсмічним коливань у грунтах та ударних хвиль у воді для знищення (знешкодження) ВП, датчики цілі яких засновані переважно на контактних принципах дії.

Як НІСД під час експерименту на суші та на воді (рис. 1) було застосоване дослідний зразок електродинамічного імпульсного джерела сейсмічних сигналів ІДД-27 [17], що надане Товариством з обмеженою відповідальністю "Югнафтогазгеологія".

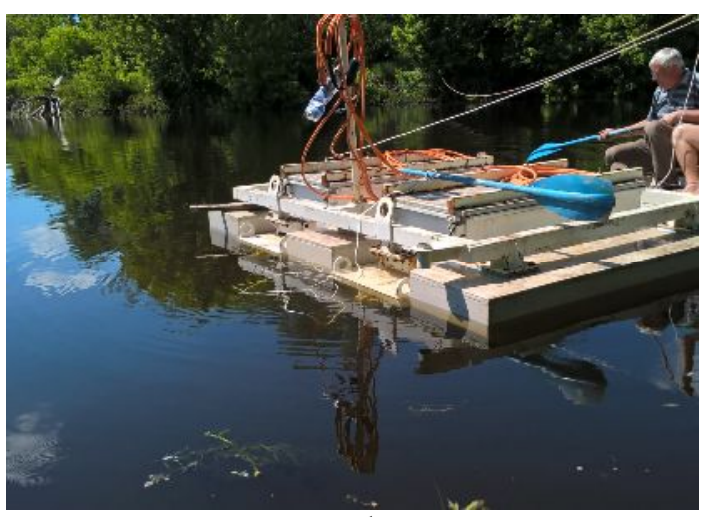

6.

Рис. 1 Використання під час експериментальних досліджень електродинамічного імпульсного джерела сейсмічних сигналів ІДД-27: а - на суші; б - на воді.

У ході планування була сформульована додаткова гіпотеза щодо можливого впливу електромагнітного поля від дії НІСД на електричні вибухові мережі та магнітні неконтактні датчики інженерних мін (IM) та саморобних вибухових пристроїв (СВП).

Отже, в якості об'єкту експериментальних досліджень обрано спосіб знищення або знешкодження ВП шляхом використання НІСД, що викликає сейсмічні коливання, ударні хвилі і електромагнітні поля в укриваючих середовищах. При цьому, задача досліджень полягала в проведенні натурного експерименту 3 метою визначення характеристик поширення сейсмічних коливань у грунті, ударних хвиль у воді i електромагнітного поля та їх впливу на датчики цілі ВП різного типу.

Планування та проведення експериментальних дослідження здійснювалось на основі методики [18], блок-схема якої наведена на рис. 2. 

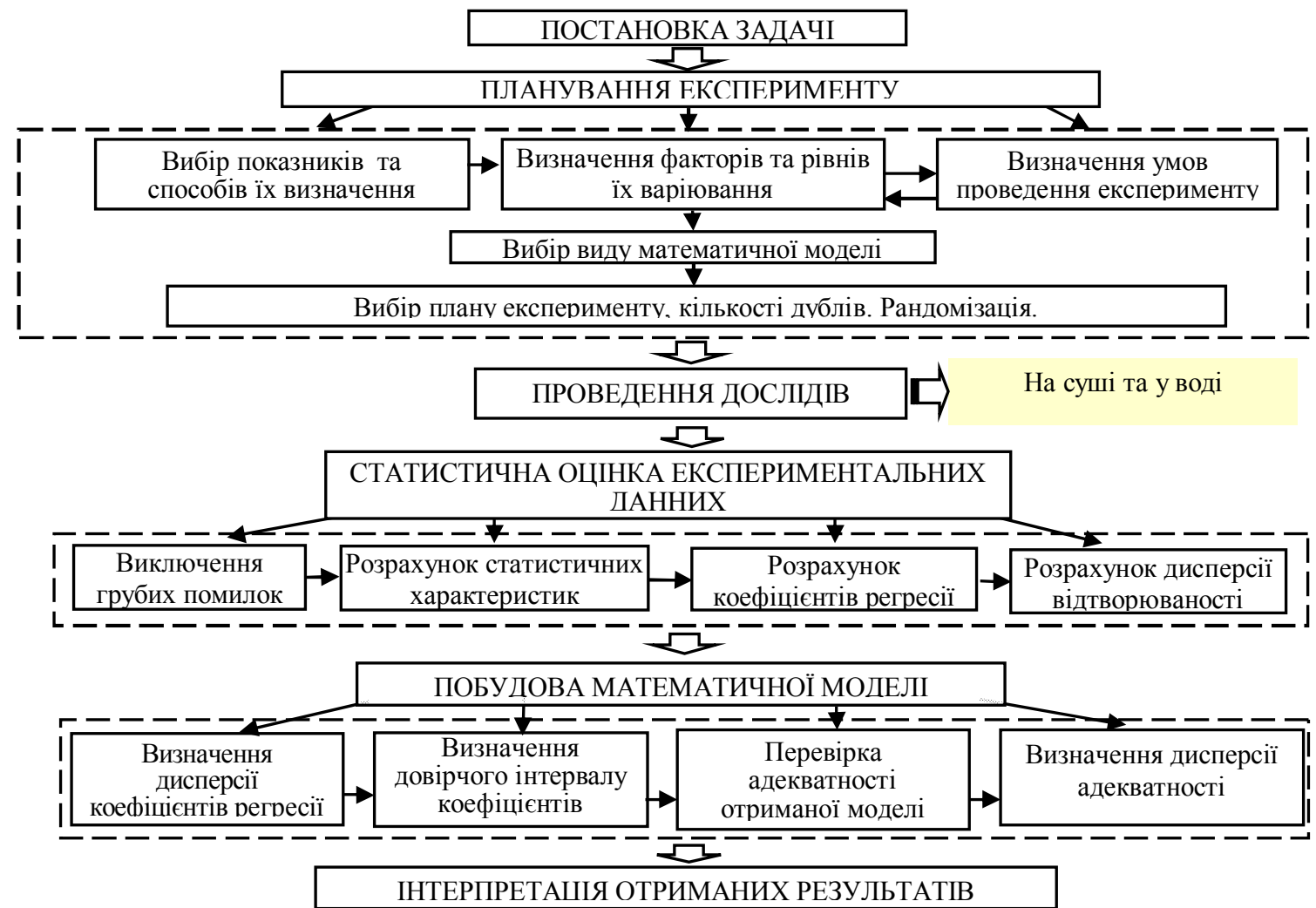

Рис. 2. Блок-схема методики планування та проведення експериментальних досліджень

Варіанти встановлення імітаційних засобів у просторі: на поверхні грунту; у грунті; на деревах; у воді. Для імітації контактних використовувались макети обривних (натяжних), натискних, штирьових, сейсмічних датчиків цілі

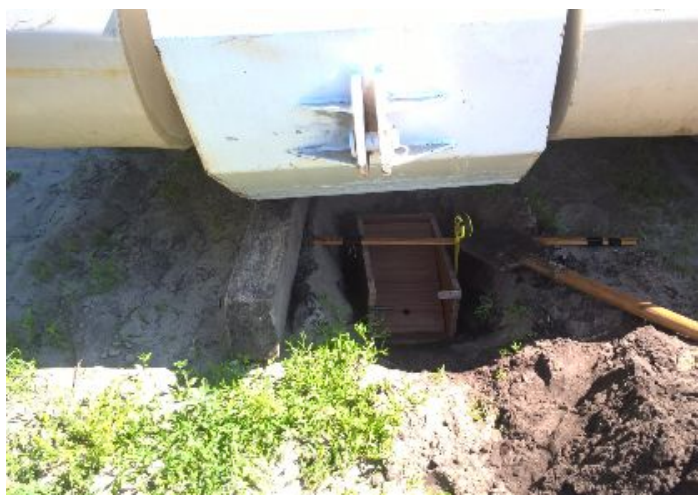

a.

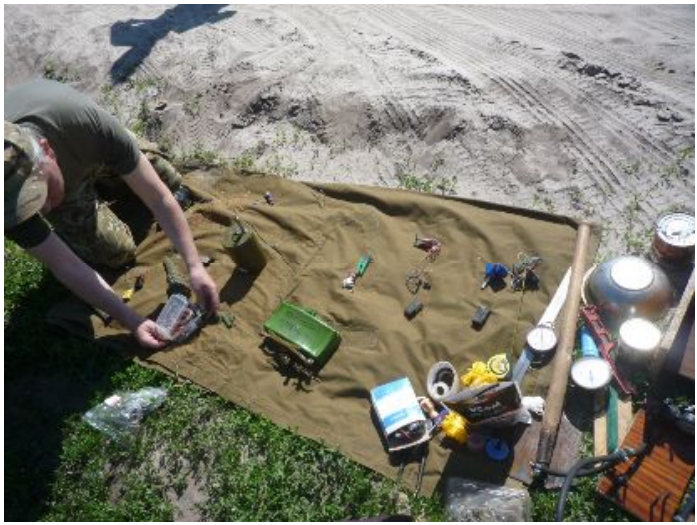

B. протитанкових (ПТМ), протитраспортних (ПТрМ), об'єктних, протипіхотних мін (ППМ), мінсюрпризів та СВП, а також штирьових датчиків цілі протидесантних мін (ПДМ) (рис. 3).

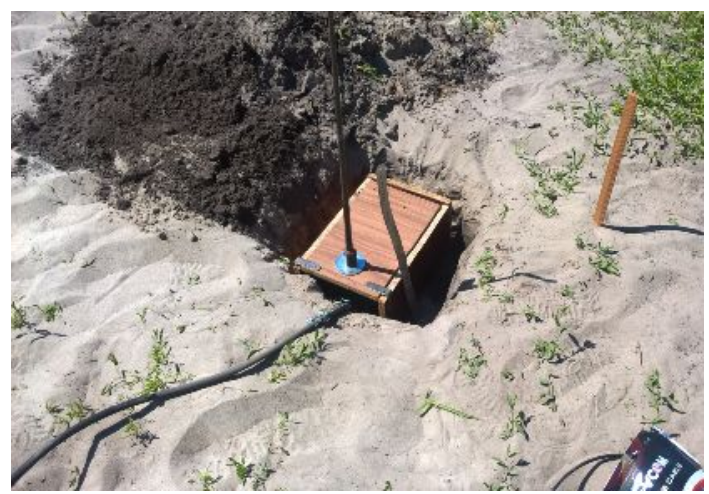

б.

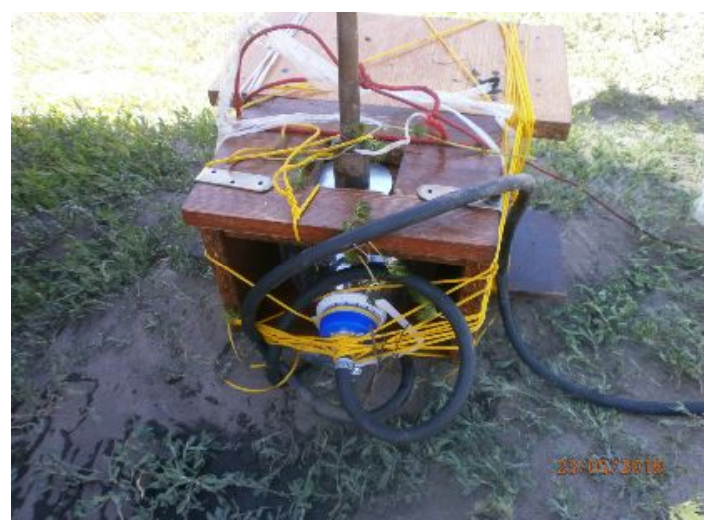

$\Gamma$.

Рис. 3. Варіанти використаних під час експериментальних досліджень макетів IM та СВП:

a - ПТМ натискної дії; б - ПТМ штиреві; в - ППМ, міни-ловушки та СВП з натяжними (обривними), сейсмічними датчиками цілі; г - ПДМ донної зі штиревим датчиком цілі 


\section{Високотехнологічні аспекти воєнного мистецтва}

Для проведення досліджень було обрано 6 основних варіантів встановлення ВП у просторі відносно НІСД за типовими схемами (рис. 4), для яких обрано фактори, показники (табл. 1).

На рис. 4 представлені варіанти досліджуваних схем розташування датчиків цілі ВП відносно НІСД:

варіант № 1 - натяжні (обривні) датчики цілі ППМ та СВП, що встановлені на поверхні грунту; варіант № 2 - натяжні (обривні) датчики цілі ППМ та СВП, що встановлені над поверхнею грунту (між деревами); варіант № 3 - натискні датчики цілі ПТМ, що встановлені під поверхнею грунту;

варіант № 4 - штиреві датчики цілі ПТМ, що встановлені під поверхнею грунту;

варіант № 5 - вібраційні датчики цілі (датчики

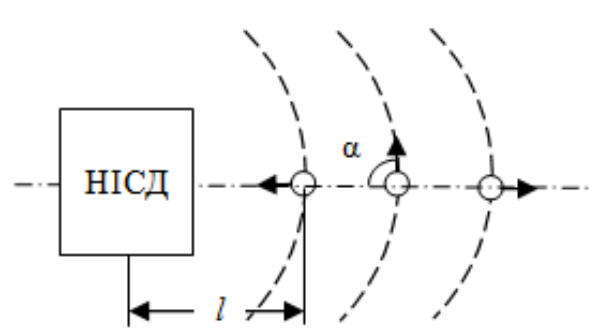

a.

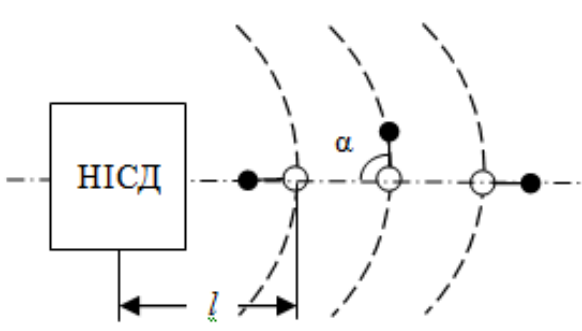

д.

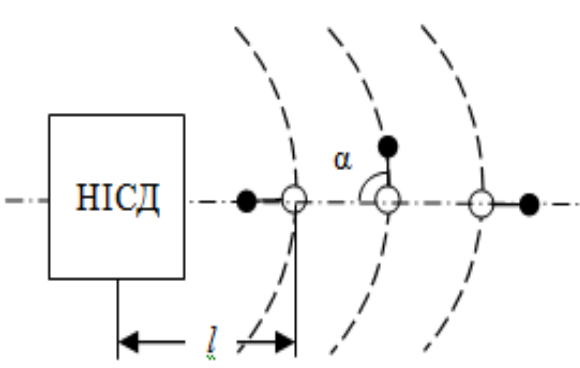

д.

Рис. 4. Схеми розташування датчиків цілі ВП відносно НІСД:

а - варіант № 1; б - варіант № 2; в- варіант № 3; г - варіант № 4; д - варіант № 5; е - варіант № 6

Таблиця

Рівні та інтервали варіювання факторів, позначення показників

\begin{tabular}{|c|c|c|c|c|c|c|}
\hline \multirow{2}{*}{ Фактори } & \multirow{2}{*}{$\begin{array}{c}\text { Кодоване } \\
\text { позначення }\end{array}$} & \multirow{2}{*}{$\begin{array}{c}\text { Інтервал } \\
\text { варіювання }\end{array}$} & \multicolumn{3}{|c|}{ Рівні факторів } & \multirow{2}{*}{$\begin{array}{c}\text { Позначення } \\
\text { показників }\end{array}$} \\
\hline & & & +1 & 0 & -1 & \\
\hline \multicolumn{7}{|c|}{ Bapiaнт № 1} \\
\hline$l$ - віддалення міни від пристрою, м & $x_{1}$ & 10 & 10 & 20 & 30 & \multirow{3}{*}{$y_{1}$} \\
\hline$\alpha-$ кут спрямування ДЦ міни, град & $x_{2}$ & 90 & 0 & 90 & 180 & \\
\hline$I$ - макс. тиск пристрою на грунт, кгс & $x_{3}$ & 10300 & 4600 & 14900 & 25200 & \\
\hline \multicolumn{7}{|c|}{ Варіант № 2} \\
\hline$l$ - віддалення міни від пристрою, м & $x_{1}$ & 10 & 10 & 20 & 30 & \multirow{3}{*}{$y_{2}$} \\
\hline$h$ - висота встановлення міни, м & $x_{2}$ & 0,5 & 0,5 & 1,0 & 1,5 & \\
\hline$I$ - макс. тиск пристрою на грунт, кгс & $x_{3}$ & 10300 & 4600 & 14900 & 25200 & \\
\hline
\end{tabular}

руху) ПТрМ та СВП, що встановлені на поверхні грунту;

варіант № 6 - штиреві датчики цілі ПДМ, що встановлені у воді.

Показниками, значення яких визначались у ході експерименту (табл. 1), є:

$y_{1}$ - питомий імпульс $\left(i_{1}\right.$, кгс/см²), визначається через відстань переміщення чеки зривника;

$y_{2}-$ питомий імпульс $\left(i_{2}\right.$, кгс/см²), визначається через відстань переміщення чеки зривника;

$y_{3}-$ питомий імпульс $\left(i_{3}\right.$, кгс/см $\left.{ }^{2}\right)$, визначається через тиск;

$y_{4}$ - питомий імпульс $\left(i_{4}\right.$, кгс/см$\left.{ }^{2}\right)$, визначається через тиск;

$y_{5}$ - частота спрацювання зривника $(P)$;

$y_{6}-$ питомий імпульс $\left(i_{5}\right.$, кгс/см $\left.{ }^{2}\right)$, визначається через тиск.
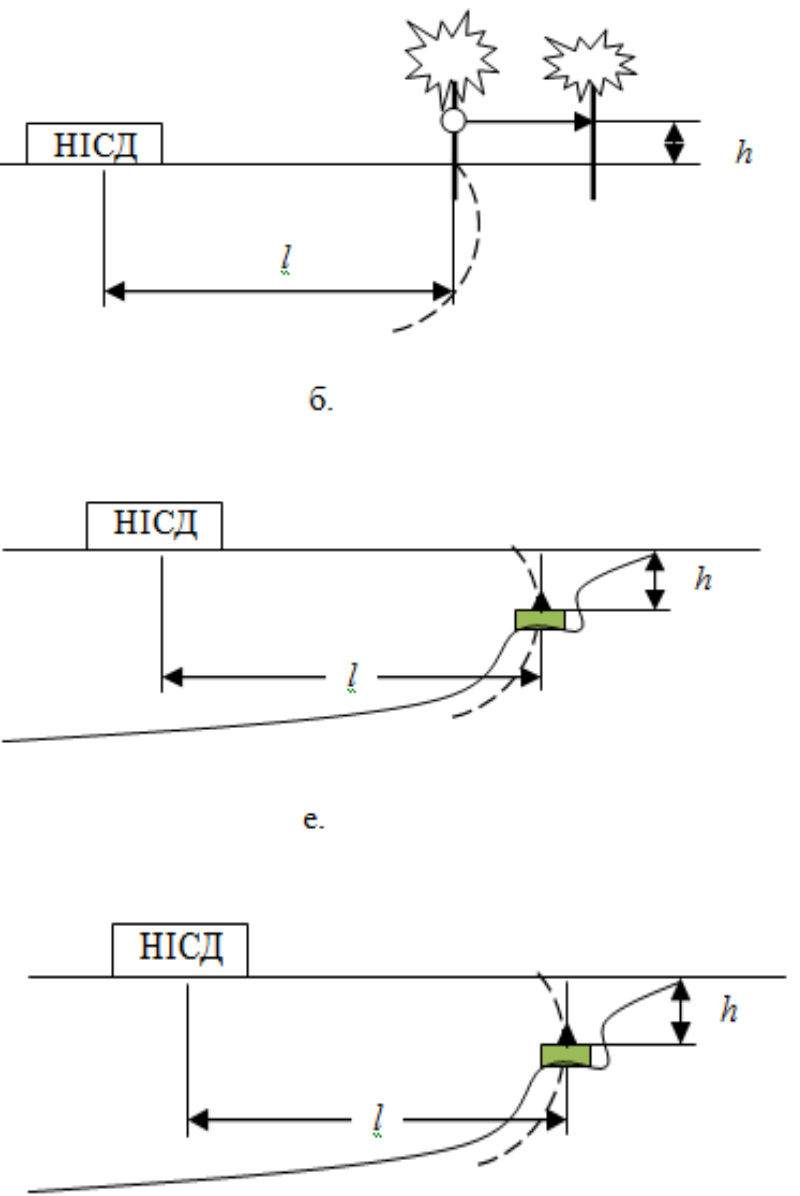

6.

e. 
High-tech aspects of martial arts

\begin{tabular}{|c|c|c|c|c|c|c|}
\hline \multirow{2}{*}{ Фактори } & \multirow{2}{*}{$\begin{array}{c}\text { Кодоване } \\
\text { позначення }\end{array}$} & \multirow{2}{*}{$\begin{array}{c}\text { Інтервал } \\
\text { варіювання }\end{array}$} & \multicolumn{3}{|c|}{ Рівні факторів } & \multirow{2}{*}{$\begin{array}{c}\text { Позначення } \\
\text { показників }\end{array}$} \\
\hline & & & +1 & 0 & -1 & \\
\hline \multicolumn{7}{|c|}{ Bapiaнт № 3} \\
\hline$l$ - віддалення міни від пристрою, м & $x_{1}$ & 4 & 0 & 4 & 8 & \multirow{3}{*}{$y_{3}$} \\
\hline$h$ - глибина встановлення міни, м & $x_{2}$ & 0,4 & 0 & 0,4 & 0,8 & \\
\hline$I$ - макс. тиск пристрою на грунт, кгс & $x_{3}$ & 10300 & 4600 & 14900 & 25200 & \\
\hline \multicolumn{7}{|c|}{ Варіант № 4} \\
\hline$l$ - віддалення міни від пристрою, м & $x_{1}$ & 3 & 2 & 5 & 8 & \multirow{2}{*}{$y_{4}$} \\
\hline$I$ - макс. тиск пристрою на грунт, кгс & $x_{2}$ & 10300 & 4600 & 14900 & 25200 & \\
\hline \multicolumn{7}{|c|}{ Bаріант № 5} \\
\hline$l$ - віддалення міни від пристрою, м & $x_{1}$ & 5 & 5 & 10 & 15 & \multirow{3}{*}{$y_{5}$} \\
\hline$\alpha-$ кут спрямування ДЦ міни, град & $x_{2}$ & 90 & 0 & 90 & 180 & \\
\hline$I$ - макс. тиск пристрою на грунт, кгс & $x_{3}$ & 10300 & 4600 & 14900 & 25200 & \\
\hline \multicolumn{7}{|c|}{ Bapiaнт № 6} \\
\hline$l$ - віддалення міни від пристрою, м & $x_{1}$ & 10 & 5 & 15 & 25 & \multirow{3}{*}{$y_{6}$} \\
\hline$h$ - глибина встановлення міни, м & $x_{2}$ & 0,25 & 0,5 & 0,75 & 1,0 & \\
\hline$I-$ макс. тиск пристрою на воду, кгс & $x_{3}$ & 10300 & 4600 & 14900 & 25200 & \\
\hline
\end{tabular}

Випробування електродинамічного імпульсного джерела сейсмічних сигналів ІДД-27 проводились влітку на відкритій місцевості на березі та на воді природної водної перешкоди. До проведення комплексних експериментальних дослідженнях залучались представники: Центрального науково-дослідного інституту озброєння i військової техніки Збройних Сил України, Товариства 3 обмеженою відповідальністю "Юг-нафтогазгеологія", Національного університету оборони України імені Івана Черняхівського, Львівського центру Інституту космічних досліджень НАН України та НКАУ, Інституту геофізики імені C.I. Субботіна НАН України.

Додатково вимірювання параметрів розповсюдження сейсмічних хвиль здійснювалось за допомогою цифрової сейсмічної станції TEXAN-125A з сейсмодатчиками GS-11D (рис. 5) та сейсмографа (велосиметра) GURALP CMG 40TD (рис. 6).

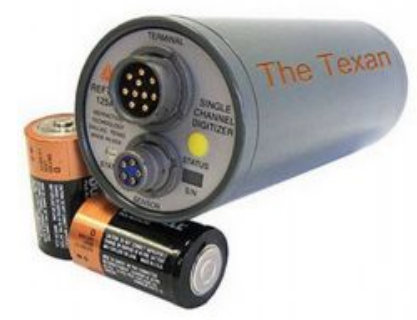

Рис. 5. Загальний вигляд автономної сейсмічної станції TEXAN-125А $з$ елементами живлення

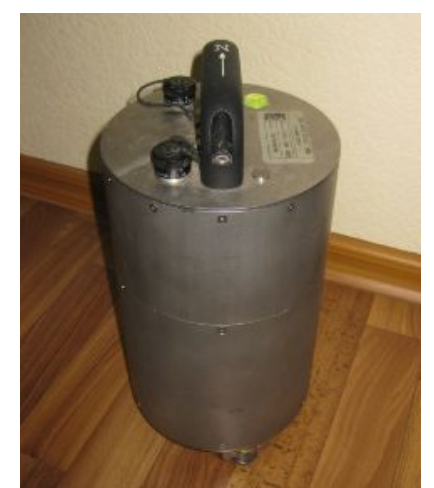

Рис. 6. Цифровий широкосмуговий сейсмограф (велосиметр) GURALP CMG-40TD
Для встановлення можливості знищення (знешкодження) ВП із неконтактними магнітними датчиками цілі проводилось дистанційне вимірювання параметрів розповсюдження електромагнітних хвиль від дії електродинамічного імпульсного джерела сейсмічних сигналів ІДД-27 за допомогою магнітотелуричної станції LEMI-423 (рис 7).

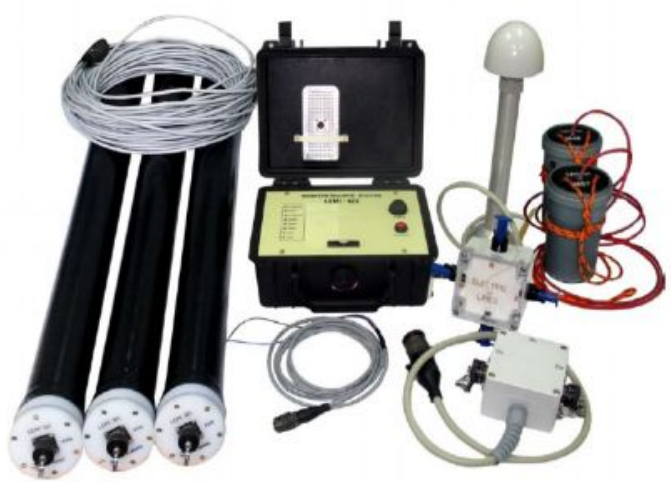

Рис. 7. Загальний вигляд комплекту магнітотелуричної станції LEMI-423

Аналіз одержаних результатів комплексних експериментальних досліджень [19-21] показав неоднозначність в питаннях можливості використання розглянутого принципу дії НІСД для знищення (знешкодження) ВП 3 різними датчиками цілі на суші та у воді.

Так результати дослідів на суші показали наступне. Натяжні (обривні) датчики цілі макетів ППМ та СВП, що встановлені на поверхні грунту та між деревами не спрацювали навіть при безпосередньому наближенні до них НІСД, тобто $y_{1}=y_{2}=0$. Це означає, що значення питомого імпульсу $i_{1}$ та $i_{2}$ впливу сейсмічних хвиль від НІСД на натяжні (обривні) датчики цілі ППМ та СВП нижче потрібного для спрацювання.

Питомий імпульс $\left(i_{3}, i_{4}\right)$, що фіксувався від НІСД на натискні та штиреві датчики цілі макетів ПТМ, які встановлені під поверхнею грунту виявилися незначними, навіть при проведені дослідів за варіантом № 3 при 
встановленні ПТМ безпосередньо під опорною поверхнею НІСД ( $\left.y_{3}=y_{4}=0\right)$.

Спрацювань вібраційних датчиків цілі (датчиків руху) макетів ПТрМ та СВП, що встановлені на поверхні грунту навіть у безпосередньому наближені до НІСД $(l<1$ м), не було зафіксовано $\left(y_{5}=0\right)$..

Результати вимірювань параметрів розповсюдження сейсмічних хвиль від НІСД за допомогою цифрової сейсмічної станції TEXAN$125 \mathrm{~A}$ з сейсмодатчиками GS-11D та сейсмографа (велосиметра) GURALP CMG 40TD наведені згідно [20] на рис. 8. Для статистичного аналізу використовувались 20 сейсмічних трас, записаних сейсмостанціями ( $Z$ компонента), та коливання грунту у тривимірному просторі, які були записані велосиметром GURALP CMG 40TD (X, Y, Z компоненти). На сейсмічних трасах відбирались ділянки 3 максимальними значеннями амплітуди коливання, на основі обробки результатів яких встановлено приріст потужності (рис. 8).

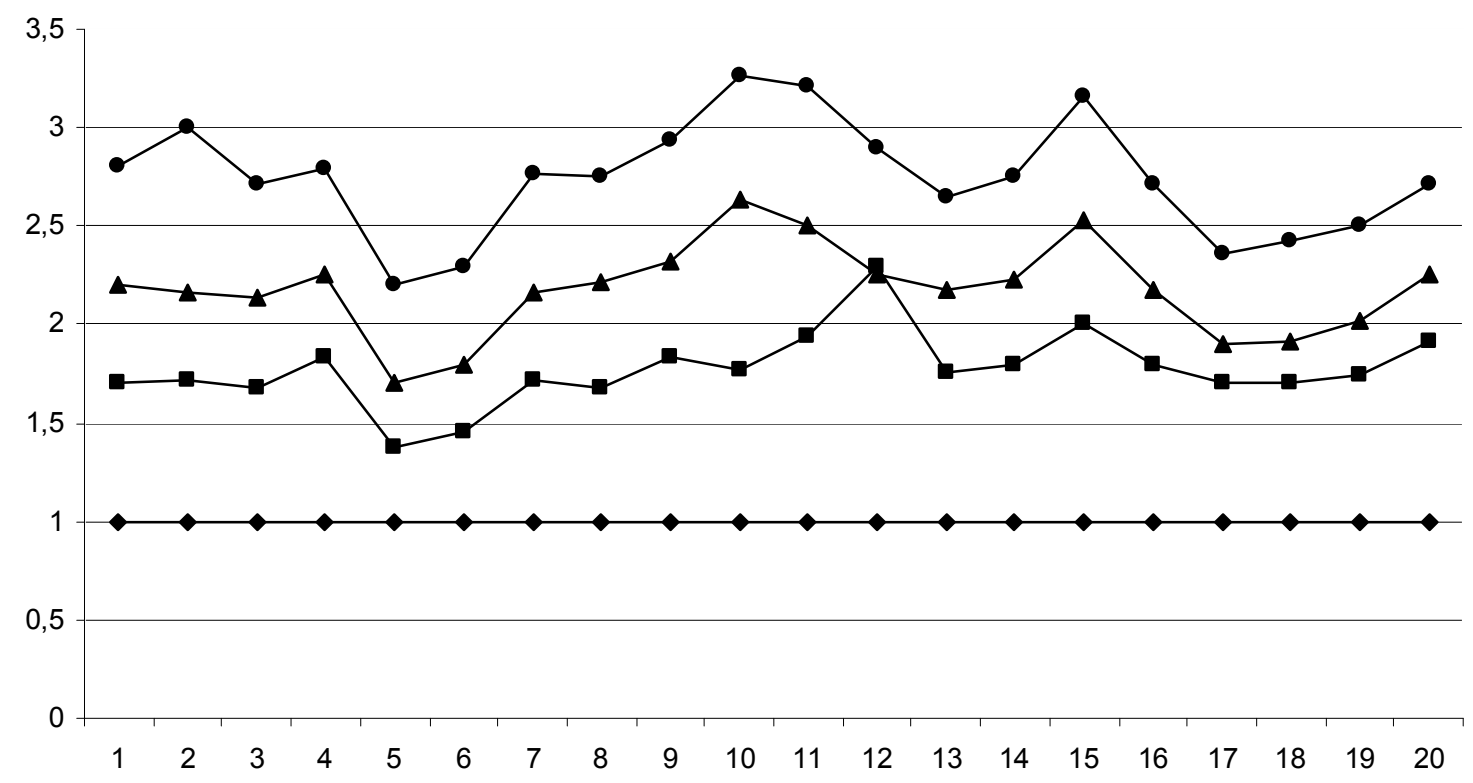

Рис. 8. Приріст потужності НІСД в залежності від кількості одночасно працюючих випромінювачів (вертикальна шкала - рази, горизонтальна - положення сейсмостанцій на поверхні землі). Позначення кривих: ромб - працював один випромінювач, квадрат - два, трикутник - три, круг - чотири [20].

Аналіз одержаних результатів (рис. 8) підтвердив можливість застосування досліджуваного принципу дії НІСД для ведення сейсмоакустичної розвідки крупних об'єктів (наприклад, авіабомб великого калібру), що знаходяться під поверхнею грунту, на відстані до 20 м. Достовірність одержаного результату підтверджується високим ступенем збіжності результатів співставлення значень вимірювань приросту потужності імпульсного джерела порахованого за допомогою двох сейсмічних приладів сейсмостанцій TEXAN-125A та велосиметра GURALP CMG 40TD.

Проведені вимірювання узагальнених параметрів НІСД, зокрема характеристики його електромагнітного поля (рис. 9) в практичному діапазоні відстаней за допомогою магнітотелуричної станціï LEMI-423 [21] дозволяють зробити наступні висновки:

практичне значення має тільки вертикальна компонента магнітного поля НІСД. Вона має величину $0.2 \ldots 1$ нТл в діапазоні відстаней 66102 м. Амплітуди інших горизонтальних компонент магнітного i електричного полів знаходяться в межах рівня завад в навколишньому середовищі; частота коливань струму в соленоїді НІСД знаходиться в районі 30 Гц. Час існування поля в межах одного ударного циклу становить близько 0,7 c;

оцінка величини магнітного моменту $M$ для серії вимірювань на відстані $r=66$ м дає величину в межах $1,4 \ldots 2,9$ кА м $^{2}$. На відстані $r=102$ м аналогічні оцінки дають величину $M$ в межах 2,1..3,2 кА·м². Для оцінки створюваного НІСД магнітного поля слід прийняти усереднену величину $M=2,4 \mathrm{\kappa A} \cdot \mathrm{M}^{2}$, що не відповідає потрібному значенню цього показника для дистанційного спрацювання неконтактних магнітних датчиків цілі ВП або приведення в дію електричних вибухових мереж.

На відміну від дослідів на суші, більше зацікавлення викликають результати (табл. 2) вимірювань дії коливань від НІСД на штировий датчик цілі макету ПДМ, що встановлений у воді на глибині 2 м. Тарирування виготовленого пристрою для вимірювання питомого імпульсу $i_{5}$, розміщеного усередині макету ПДМ (рис 3.г), показало, що збільшенню його значення на 0,5 кгс при прикладанні зусилля в центрі штиря відповідало збільшення значення тиску на 1 мм рт. ст. шкали манометру. 


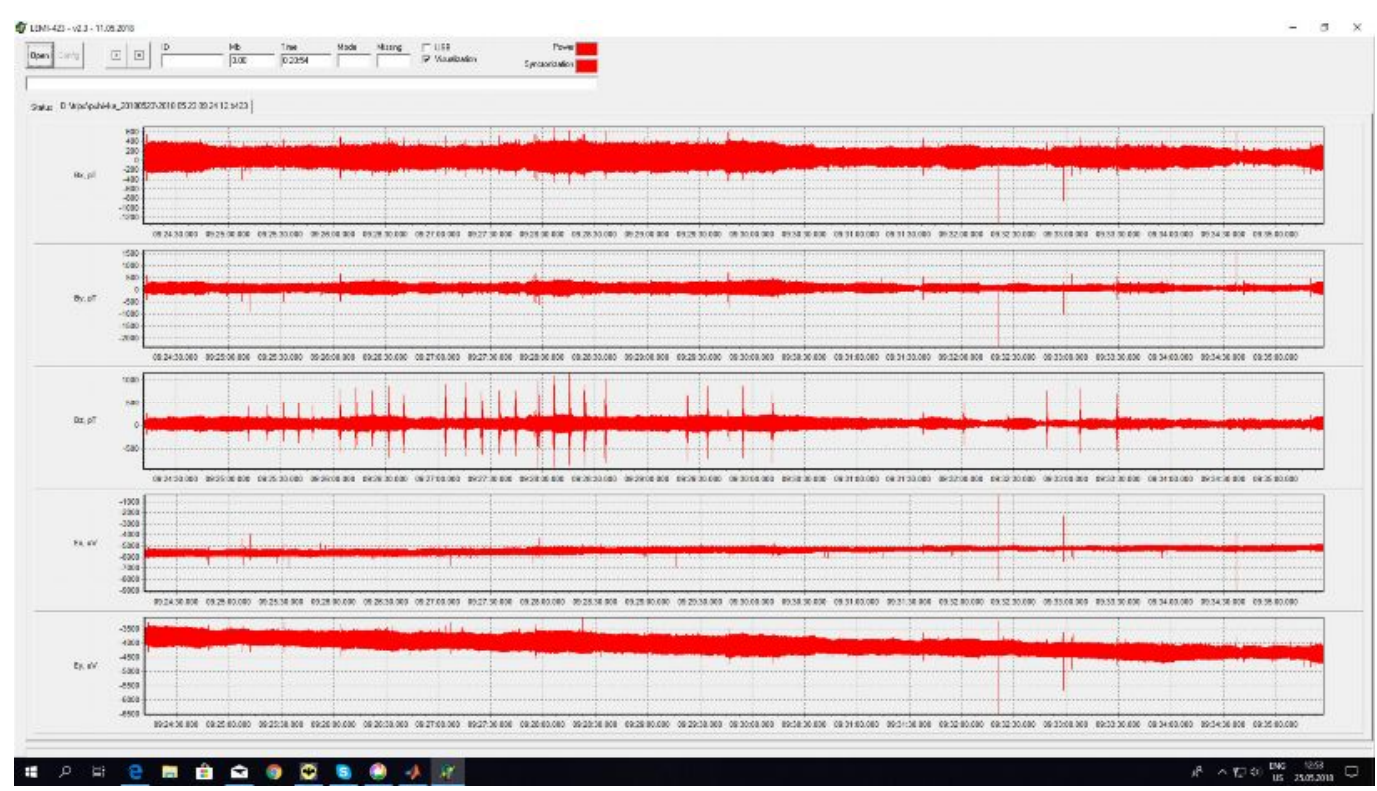

Рис. 9. Результати замірів магнітного та електричного полів.

Таблиця 2

Результати проведених експериментальних досліджень у воді [19]

\begin{tabular}{|c|c|c|c|c|c|c|c|c|c|c|c|c|c|c|c|c|c|}
\hline \multirow[b]{3}{*}{$\begin{array}{c}\text { № } \\
\text { досліду }\end{array}$} & \multirow{3}{*}{ 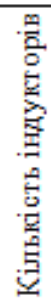 } & \multicolumn{16}{|c|}{ Значення шкали тонометра на різних відстанях, мп рт. ст. (кгс): } \\
\hline & & \multicolumn{2}{|c|}{0} & \multicolumn{2}{|c|}{1} & \multicolumn{2}{|c|}{2} & \multicolumn{2}{|c|}{3} & \multicolumn{2}{|c|}{4} & \multicolumn{2}{|c|}{5} & \multicolumn{2}{|c|}{10} & \multicolumn{2}{|c|}{15} \\
\hline & & 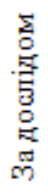 & 总 & 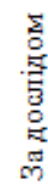 & 总 & 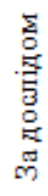 & 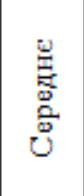 & 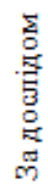 & 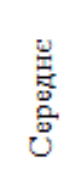 & 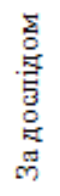 & 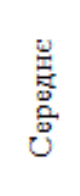 & 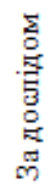 & 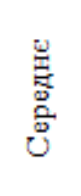 & 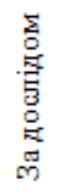 & 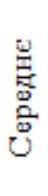 & 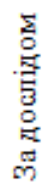 & 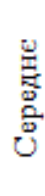 \\
\hline 1 & \multirow{5}{*}{1} & - & \multirow{5}{*}{-} & 10 & \multirow{5}{*}{$\begin{array}{c}9,2 \\
(4,6)\end{array}$} & 4 & \multirow{5}{*}{$\begin{array}{c}4,4 \\
(2,2)\end{array}$} & 1 & \multirow{5}{*}{$\begin{array}{c}1,2 \\
(0,6)\end{array}$} & 0 & \multirow{5}{*}{0} & 0 & \multirow{5}{*}{0} & 0 & \multirow{5}{*}{0} & 0 & \multirow{5}{*}{0} \\
\hline 2 & & - & & 9 & & 5 & & 2 & & 0 & & 0 & & 0 & & 0 & \\
\hline 3 & & - & & 10 & & 4 & & 1 & & 0 & & 0 & & 0 & & 0 & \\
\hline 4 & & - & & 8 & & 4 & & 1 & & 0 & & 0 & & 0 & & 0 & \\
\hline 5 & & - & & 9 & & 5 & & 1 & & 0 & & 0 & & 0 & & 0 & \\
\hline 6 & \multirow{5}{*}{2} & - & \multirow{5}{*}{-} & 15 & \multirow{5}{*}{$\begin{array}{l}15,4 \\
(7,7)\end{array}$} & 9 & \multirow{5}{*}{$\begin{array}{c}9 \\
(4,5)\end{array}$} & 4 & \multirow{5}{*}{$\begin{array}{c}3,8 \\
(1,9)\end{array}$} & 2 & \multirow{5}{*}{$\begin{array}{c}1,2 \\
(0,6)\end{array}$} & 0 & \multirow{5}{*}{0} & 0 & \multirow{5}{*}{0} & 0 & \multirow{5}{*}{0} \\
\hline 7 & & - & & 16 & & 8 & & 3 & & 1 & & 0 & & 0 & & 0 & \\
\hline 8 & & - & & 15 & & 9 & & 4 & & 0 & & 0 & & 0 & & 0 & \\
\hline 9 & & - & & 16 & & 9 & & 4 & & 1 & & 0 & & 0 & & 0 & \\
\hline 10 & & - & & 15 & & 10 & & 4 & & 2 & & 0 & & 0 & & 0 & \\
\hline 11 & & - & & 20 & & 16 & & 9 & & 4 & & 1 & & 0 & & 0 & \\
\hline 12 & & - & & 19 & & 15 & & 9 & & 4 & & 2 & & 0 & & 0 & \\
\hline 13 & 3 & - & - & 20 & & 15 & & 10 & $\begin{array}{c}9,4 \\
4\end{array}$ & 4 & $\begin{array}{c}3,8 \\
0\end{array}$ & 1 & $\begin{array}{l}1,4 \\
0.7\end{array}$ & 0 & 0 & 0 & 0 \\
\hline 14 & & - & & 21 & & 16 & & 9 & & 3 & & 1 & & 0 & & 0 & \\
\hline 15 & & - & & 19 & & 15 & & 10 & & 4 & & 2 & & 0 & & 0 & \\
\hline 16 & & - & & 24 & & 21 & & 14 & & 11 & & 4 & & 0 & & 0 & \\
\hline 17 & & - & & 23 & & 19 & & 16 & & 9 & & 5 & & 0 & & 0 & \\
\hline 18 & 4 & - & - & 24 & 23,8 & 20 & 20,8 & 14 & 14,8 & 10 & $\begin{array}{c}9,4 \\
\end{array}$ & 4 & 4 & 0 & 0 & 0 & 0 \\
\hline 19 & & - & & 25 & $(11,9)$ & 21 & $(10,4)$ & 15 & & 8 & $(4,7)$ & 3 & (2) & 0 & & 0 & \\
\hline 20 & & - & & 23 & & 19 & & 15 & & 9 & & 4 & & 0 & & 0 & \\
\hline
\end{tabular}

Синтез отриманих середніх значень результатів вимірювань під час проведення експерименту на воді наведено на рис. 10.

Аналіз результатів досліджень (рис. 10) показав, що у воді мінімальне значення зміни тиску на штировий датчик цілі 1,4 мм рт. ст. зафіксоване при роботі 3-х індукторів НІСД та 2 мм рт. ст. - при роботі 4-х індукторів НІСД при поверхневому віддалені 5 м від центру встановленого макету ПДМ. Максимальне значення зміни тиску на штировий датчик цілі 23,8 мм рт. ст. ( $i_{5}=11,9$ кгс) зафіксовано при роботі 4-х індукторів НІСД при поверхневому віддалені 1 м від центру встановленого макету ПДМ. Таке значення питомого імпульсу $i_{5}$ на $30 \%$ нижче ніж мінімально потрібне значення зусилля спрацювання міни типу ПДМ-1М, а отже $\epsilon$ недостатнім. Для забезпечення спрацювання ПДМ у воді значення питомого імпульсу ударної хвилі від дії НІСД із врахуванням потреби віддалення на безпечну відстань (близько 10 м) потрібно значно збільшити. 
$I$, ктс

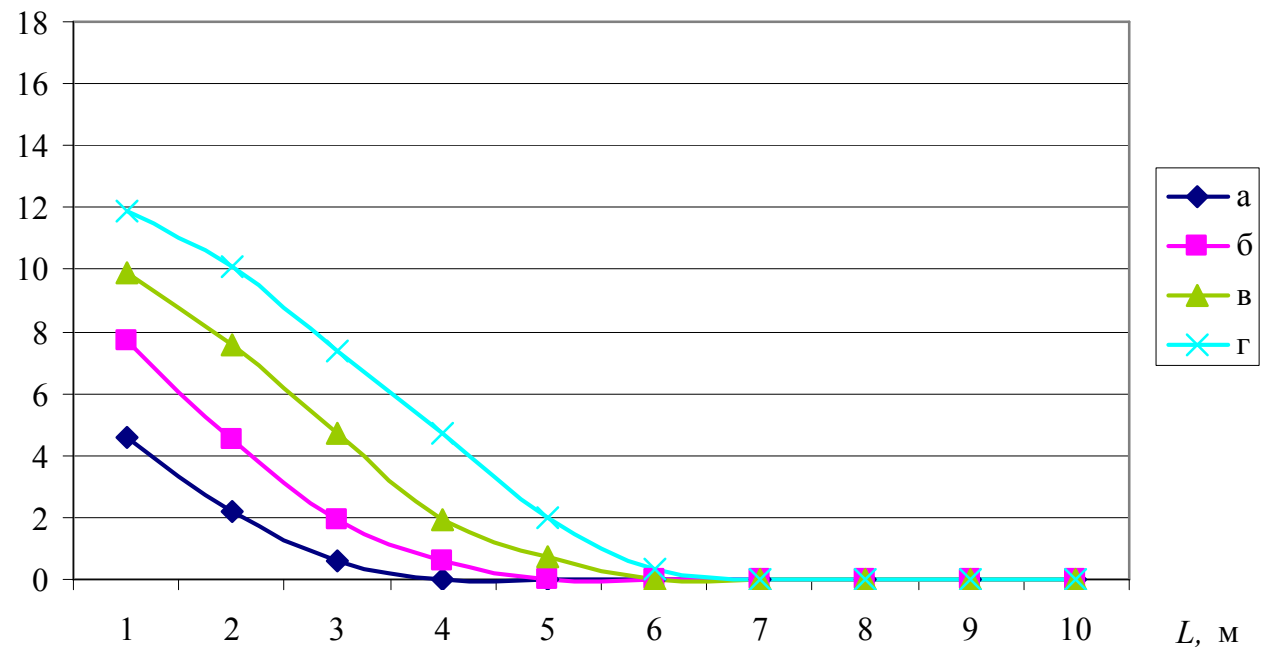

Рис. 10. Залежність тиску зафіксованого тонометром від дальності знаходження пристрою збудження імпульсних сейсмічних коливань: а - значення тиску при дії 1-го індуктору; б - значення тиску при дії 2-х індукторів; в - значення тиску при дії 3-х індукторів; в - значення тиску при дії 4-х індукторів.

\section{Висновки й перспективи подальших досліджень}

Узагальнюючи вищевикладене, можна зробити наступні висновки.

1. Вимірювання за допомогою сейсмічних приладів сейсмостанції TEXAN-125A та велосиметра GURALP CMD 40TD підтвердили можливість застосування досліджуваного принципу дії НІСД для ведення сейсмоакустичної розвідки крупних об'єктів (наприклад, авіабомб великого калібру).

2. Результати вимірювань значень тиску пристроєм збудження імпульсних сейсмічних коливань ІДД-27 у воді підтвердили гіпотезу щодо можливість застосування пристроїв даного типу для знищення (знешкодження) окремих типів ПДМ при збільшенні потужності сейсмічних коливань.

3. Проведені вимірювання характеристики електромагнітного поля НІСД в практичному

\section{Лimepamypa}

1. Протимінна діяльність в Україні потребує нових підходів, - МінТОТ // Електронний ресурс. Режим доступу: https:/ua.112.ua/suspilstvo/protyminna-diialnist-v-ukrainipotrebuie-novykh-pidkhodiv-mintot-390493.html.

2. Мінна загроза: щодесята жертва підривів - дитина // Електронний ресурс. Режим доступу: https://rubryka.com/article/minna-zagroza. З. Польских Н.Л. Некоторые выводы по итогам инженерного обеспечения миротворческих сил в ходе грузино-абхазского конфликта// Арм. сб. 1997. № 1. С. 37-39. 4. Жуков С. Опыт разминирования местности в условиях локальных военных конфликтов // Зарубежное военное обозрение. № 6, 1998. С. 14-19. 5. Жуков С. Опыт разминирования местности в Боснии и Герцеговине // Зарубежное военное обозрение. № 8, 1998. С. 18-22. 6. Свірський С. Ліван: місія триває // Військо України. № 3, 2003. С. 4-7. 7. Підсумковий звіт про виконання бойових завдань саперними підрозділами ЗС України в Ісламській Республіці Афганістан у складі Литовської групи з реконструкції провінції Гор (ГРП) за діапазоні відстаней за допомогою магнітотелуричної станції LEMI-423 вказують про недостатність їх значень для забезпечення спрацювання неконтактних магнітних датчиків цілі ІМ та СВП або завчасного приведення в дію електричних вибухових мереж навіть при значному їх наближенні до НІСД.

4. В цілому результати вимірювань показали, що існуючий на теперішній час пристрій збудження імпульсних сейсмічних коливань ІДД27 виробництва ТОВ “Юг-нафтогазгеологія" має недостатню потужність для знешкодження ВП 3 будь-якими датчиками цілі, що встановлені в грунт або на поверхні грунту.

Як напрямок подальших досліджень $\epsilon$ обгрунтування тактико-технічних вимог до перспективного засобу знищення (знешкодження) ПДМ 3 контактними датчиками цілі, в основу принципу дії якого лежить використання енергії збуджених імпульсних хвиль у воді.

період $з$ листопада 2010 р. по листопад 2011 р. К.: ГШ ЗСУ, 2012. 47 с. 8. Петренко Е. С. Некоторые технические особенности решения проблемы гуманітарного разминирования // Специальная техника, 2002. №3. С. 1213. 9. Керівництво по управлінню операціями по розмінуванню (офіційний переклад) // МСПМД (IMAS) 07.10. - USA New York: ЮHMAC OOH, 2001. - 30 c. // Електронний ресурс. Режим доступу: http://www.mineactionstandards.org. 10. Щербаков Г. Н. Новые методы обнаружения скрытых объектов: монография. М.: ООО Эльф ИПР, 2011. 503 с. 11. Карев А., Раевский В., Коняев Ю., Румянцев А., Аверченко А. Мобильний комплекс обнаружения взрывчатых веществ. Технология разминирования XXI века // Электроника: Наука. Технологии. Бизнес, 2000. № 1. С. 54-58. 12. Корытченко К. В. Экспериментальное исследование применения объемных шланговых зарядов / К.В. Корытченко, Д.П. Дубинин, С.В. Говаленков // Атуальні проблеми технічних та природничих наук у 
забезпеченні цивільного захисту: III міжнар. наук.-практ. конф., 6-7 квітня 2010 р.: тези допов. - Черкаси, 2010. - С. 107 - 110. 13. Ментус І. Е. Ефективність інженерних боєприпасів: навчальний посібник. Кам'янецьПодільський: ФВП ПДАТУ, 2008. 80 с. 14. Бочаров О.А. Методы дистанционного обезвреживания ВОП // Артиллерийское и стрелковое вооружение / Конструкторское бюро “Артиллерийское вооружение”. К.: МППУ , 2008. № 2. С. 34-37. 15. Саламахин Т.М. Основы моделирования и боевая эффективность зарядов разрушения. Ч. 1. М.: ВИА, 1983. 160 с. 16. Ментус I.E. Ефективність зарядів руйнування: навчальний посібник. Кам'янець-Подільський: ФВП ПДАТУ, 2008. 80 с. 17. Отчет о заводских приемочных испытаниях опытного образца электродинамического импульсного источника сейсмических сигналов ИДД-27. - Кимры: ЗАО “Геосвип", 2013. - 43 с. 18. Цивин М.Н. Многофакторный эксперимент: графическая интерпретация данных - К.: ИГиМ, 2002. - 120 с. 19. Звіт про проведення експериментальних досліджень 23.05.2018. - К.: ЦНДІ ОВТ ЗС України та ТОВ “Юг-нафтогазгеологія”, 2018. 8 с. 20. Науково-технічний звіт по темі: “Дослідження потужності імпульсного електор-механічного джерела сейсмічних хвиль на суші та у воді, при різній кількості одночасно працюючих індукторах". - К.: Інститугу геофізики ім. С.І. Субботіна НАН України, 2018. - 25 с. 21. Звіт про проведення спостережень з магнітотелуричною станцією LEMI-42. - Львів: Львівського центру Інституту космічних досліджень НАН України та НКАУ, 2018. - 7 с.

\title{
ИССЛЕДОВАНИЕ ВОЗМОЖНОСТИ ИСПОЛЬЗОВАНИЯ НЕВЗРЫВЧАТОЕ ИМПУЛЬСНОГО СЕЙСМИЧЕСКОГО ИСТОЧНИКИ ДЛЯ УНИЧТОЖЕНИЯ ВЗРЫВНЫХ УСТРОЙСТВ
}

\author{
Владимир Иванович Коцюруба (доктор технических наук, доцент) ${ }^{1}$ \\ Анатолий Степанович Довгополый (доктор технических наук, профессор) ${ }^{2}$ \\ Олег Михайлович Гусляков (кандидат технических наук) ${ }^{2}$ \\ Николай Павлович Лойко ${ }^{3}$
}

\section{${ }^{1}$ Национальный университет обороны Украины имени Ивана Черняховского, Киев, Украина \\ ${ }^{2}$ Центрального научно-исследовательского института вооружения и военной техники Вооруженных Сил, Киев, Украина \\ ${ }^{3}$ Общество с ограниченной ответственностью "Юг-нафтогазгеология", Киев, Украина}

Исследуется проблема гуманитарного разминирования и возможность использования принципа действия, что положено в основу невзрывного импульсного сейсмического источника для уничтожения (обезвреживания) взрывных устройств с различными датчиками иели, установленные на суше или 8 воде. Как невзрывное импульсное сейсмическое источник применено опытный образеи электродинамического импульсного источника сейсмических сигналов ИСД-27 предоставлень обществом с ограниченной ответственностью "Юг-нафтогазгеология". На основе анализа результатов проведенного комплексного натурного эксперимента проверены гипотезы о возможности использования устройства данного типа для уничтожения (обезврежсивания) взрывных устройств путем воздействия возбужденных поверхностных $и$ эпицентральным сейсмических $и$ электромагнитных волн на контактные или неконтактные датчики цели взрывных устройств. Как контактные использовались макеты обрывные (натяжных), нажимных, штыревых, сейсмических датчиков иели противотанковых, протитраспортних, объектных, противопехотных мин, минсюрпризов и самодельных взрывных устройств, а также штыревых датчиков иели противодесантных мин.

Кроме того измерения параметров распространения сейсмических волн осуществлялось с помощью ичифровой сейсмической станции TEXAN-125A с сейсмодатчики GS-11D и сейсмографа Guralp CMD 40TD. С иелью установления возможности уничтожения (обезвреживания) взрывных устройств с неконтактными магнитными датчиками цели проводилось дистанционное измерение параметров распространения электромагнитных волн от действия электродинамического импульсного источника сейсмических сигналов ИСД-27 с помощью магнитотеллурического станции LEMI-423. Анализ полученных результатов показал неоднозначность в вопросах возможности использования рассматриваемого принципа действия невзрывного импульсного сейсмического источника для уничтожения (обезвреживания) взрывных устройств с различными датчиками цели на суше и в воде.

Ключевые слова: гуманитарное разминирование; уничтожение (обезвреживание) датчик иели; взрывное устройство; взрывоопасный предмет; невзрывное импульсное сейсмическое источник; сейсмические волны; электромагнитное излучение.

\section{STUDIES ON THE POSSIBILITY OF USING THE NON-EXPLOSIVE PULSE SEISMIC SOURCE TO NEUTRALIZE EXPLOSION DEVICES}

\author{
Volodymyr Kotsiuruba (Doctor of Technical Sciences, Associate Professor) ${ }^{1}$ \\ Anatolii Dovhopolyi (Doctor of Technical Sciences, Associate Professor) ${ }^{2}$ \\ Oleh Husliakov (Candidate of Technical Sciences) ${ }^{2}$ \\ Mykola Loiko ${ }^{3}$
}




\section{${ }^{1}$ National Defence University of Ukraine named after Ivan Cherniakhovsky, Kyiv, Ukraine \\ ${ }^{2}$ Of the Central Research Institute of Armed Forces and Military Equipment of the Armed Forces, Kyiv, Ukraine \\ ${ }^{3}$ Yug-Neftegazgeologiya Limited Liability Company, Kyiv, Ukraine}

The problem of humanitarian demining and the possibility of using the principle of action that underlies the non-explosive pulse seismic source for the destruction (disposal) of explosive devices with different target sensors mounted on land or in water is investigated. As a non-explosive impulse seismic source a prototype of the electrodynamic impulse source of seismic signals IDD-27 was used, provided by the limited liability company "Yuh-Naftohazgheolohiia". Based on the analysis of the results of a comprehensive field experiment, the hypotheses were tested regarding the possibility of using a device of this type to destroy (neutralize) the explosive devices by the influence of excited surface and both epicentral seismic and electromagnetic waves on the contact or non-contact sensors of the target explosive devices. As the contact ones were used layouts of break-wire (tensioning), push, pin, seismic target sensors; anti-tank, anti-transport, object, anti-personnel land mines, mines-surprises, and improvised explosive devices as well as anti-landing target pin sensors.

In addition, seismic wave propagation parameters were measured using a TEXAN-125A digital seismic station with GS-11D seismic sensors and a Guralp CMD 40TD seismograph. In order to establish the possibility of destruction (neutralization) of explosive devices with non-contact magnetic sensors of the target, remote measurements of the parameters of propagation of electromagnetic waves from the action of the electrodynamic pulse source of seismic signals IDD-27 were carried out by means of the magnetoteluric station LEMI-423. The analysis of the obtained results showed ambiguity regarding the possibility of using the considered principle of action of non-explosive pulsed seismic source for destruction (neutralization) of explosive devices with different sensors of the target on land and in water.

Key words: humanitarian demining; destruction (neutralization); target sensor; explosive device; explosive object; non-explosive pulsed seismic source; seismic waves; electromagnetic radiation.

\section{References}

1. Protyminna dijaljnistj $\mathrm{v}$ Ukrajini potrebuje novykh pidkhodiv, - MinTOT // Elektronnyj resurs. Rezhym dostupu: https://ua.112.ua/suspilstvo/protyminna-diialnist-vukraini-potrebuie-novykh-pidkhodiv-mintot-390493.html.

2. Minna zaghroza: shhodesjata zhertva pidryviv - dytyna // Elektronnyj resurs. Rezhym dostupu: https://rubryka.com/article/minna-zagroza.

3. Poljskykh N.L. Nekotorыe vыvodы po ytogham ynzhenernogho obespechenyja myrotvorcheskykh syl v khode ghruzyno-abkhazskogho konflykta// Arm. sb. 1997. № 1. S. 37-39. 4. Zhukov S. Opыt razmynyrovanyja mestnosty v uslovyjakh lokaljnыkh voennыkh konflyktov // Zarubezhnoe voennoe obozrenye. № 6, 1998. S. 14-19. 5. Zhukov S. Opyt razmynyrovanyja mestnosty v Bosnyy y Gherceghovyne // Zarubezhnoe voennoe obozrenye. № 8, 1998. S. 18-22. 6. Svirsjkyj Je. Livan: misija tryvaje // Vijsjko Ukrajiny. № 3, 2003. S. 4-7. 7. Pidsumkovyj zvit pro vykonannja bojovykh zavdanj sapernymy pidrozdilamy ZS Ukrajiny v Islamsjkij Respublici Afghanistan u skladi Lytovsjkoji ghrupy z rekonstrukciji provinciji Ghor (GhRP) za period z lystopada 2010 r. po lystopad 2011 r. K.: GhSh ZSU, 2012. 47 s. 8. Petrenko E. S. Nekotorye tekhnycheskye osobennosty reshenyja problemb ghumanitarnogho razmynyrovanyja // Specyaljnaja tekhnyka, 2002. №3. S. 12-13. 9. Kerivnyctvo po upravlinnju operacijamy po rozminuvannju (oficijnyj pereklad) // MSPMD (IMAS) 07.10. - USA New York: JuNMAS OON, 2001. - 30 s. // Elektronnyj resurs. Rezhym dostupu: http://www.mineactionstandards.org. 10. Shherbakov Gh. N. Novye metody obnaruzhenyja skrytykh obektov: monoghrafyja. M.: OOO Эljf YPR, 2011. 503 s. 11. Karev A., Raevskyj V., Konjaev Ju., Rumjancev A., Averchenko A. Mobyljnyj kompleks obnaruzhenyja vzryvchatykh veshhestv. Tekhnologhyja razmynyrovanyja XXI veka // Эlektronyka: Nauka. Tekhnologhyy. Byznes, 2000. № $1 . \quad$ S. 54-58.
12. Korytchenko K. V. Eksperymentaljnoe issledovanye prymenenyja obemnykh shlanghovykh zarjadov / K.V. Korytchenko, D.P. Dubynyn, S.V. Ghovalenkov // Atualjni problemy tekhnichnykh ta pryrodnychykh nauk $\mathrm{u}$ zabezpechenni cyviljnogho zakhystu: III mizhnar. nauk.prakt. konf., 6-7 kvitnja 2010 r.: tezy dopov. - Cherkasy, 2010. - S. 107 - 110. 13. Mentus I. E. Efektyvnistj inzhenernykh bojeprypasiv: navchaljnyj posibnyk. Kam'janecj-Podiljsjkyj: FVP PDATU, 2008. 80 s. 14. Bocharov O.A. Metody dystancyonnogho obezvrezhyvanyja VOP // Artylleryjskoe y strelkovoe vooruzhenye / Konstruktorskoe bjuro "Artylleryjskoe vooruzhenye”. K.: MPPU , 2008. № 2. S. 34-37. 15 Salamakhyn T.M. Osnovy modelyrovanyja y boevaja effektyvnostj zarjadov razrushenyja. Ch. 1. M.: VYA, 1983. 160 s. 16. Mentus I.E. Efektyvnistj zarjadiv rujnuvannja: navchaljnyj posibnyk. Kam'janecj-Podiljsjkyj: FVP PDATU, 2008. 80 s. 17. Otchet o zavodskykh pryemochnыkh yspыtanyjakh opыtnogho obrazca эlektrodynamycheskogho ympuljsnogho ystochnyka sejsmycheskykh syghnalov YDD-27. - Kymrы: ZAO "Gheosvyp", 2013. - 43 s. 18. Cyvyn M.N. Mnoghofaktornыj эksperyment: ghrafycheskaja ynterpretacyja dannыkh - K.: YGhyM, 2002. - 120 s. 19. Zvit pro provedennja eksperymentaljnykh doslidzhenj 23.05.2018. - K.: CNDI OVT ZS Ukrajiny ta TOV "Jughnaftoghazgheologhija”, 2018. 8 s. 20. Naukovo-tekhnichnyj zvit po temi: "Doslidzhennja potuzhnosti impuljsnogho elektor-mekhanichnogho dzherela sejsmichnykh khvylj na sushi ta u vodi, pry riznij kiljkosti odnochasno pracjujuchykh induktorakh". - K.: Instytutu gheofizyky im. S.I. Subbotina NAN Ukrajiny, 2018. - 25 s. 21. Zvit pro provedennja sposterezhenj $\mathrm{z}$ maghnitotelurychnoju stancijeju LEMI-42. - Ljviv: Ljvivsjkogho centru Instytutu kosmichnykh doslidzhenj NAN Ukrajiny ta NKAU, 2018. $7 \mathrm{~s}$. 